\title{
Evaluation of urban planning strategies with a versatile urban growth model
}

\author{
D. Vye \& F. Rousseaux \\ Institut du Littoral et de l'Environnement, \\ UMR 6250 Université de La Rochelle/CNRS, France
}

\begin{abstract}
La Rochelle, France witnessed an important growth of its permanent and seasonal population during the second half of the twentieth century. Its attractive coastal position is the main reason for this increase, which led to a massive urban spread, particularly in La Rochelle peripheral municipalities. Which are the strategies used by local public authorities to take into account social and environmental problems? While it has been very innovative since 1970 in regard to urban ecology and sustainable development, does La Rochelle still have today the capacity to tend towards the "ideal sustainable city"? On the contrary, is La Rochelle powerless, or even more complicit in the urban sprawl phenomenon? The purpose of this paper is to focus on one factor that particularly influences urban growth: local urban policies and planning strategies through planning documents analysis. For this, an urban growth model based on a cellular automata paradigm is used. In this model, the space is described as a grid, for each non built cell, with a graduated probability of building. This probability of building is based on the analysis of planning rules (e.g. urban planning regulation framework). The example of the correlation between these planning rules and local urban growth is described in this paper. The model enables the simulation of alternative urban growth scenarios. It helps one to estimate how alternative planning could affect non built areas. This model aims at helping the elaboration of future planning documents. The control of La Rochelle's urban spread is one of the main stakes to be taken into account in the future land development plan (Schema de COherence Territoriale: SCOT). The SCOT is currently being elaborated in La Rochelle.
\end{abstract}

Keywords: planning strategies, sustainable city, GIS, modelling, urban spread. 


\section{Introduction}

La Rochelle, France, experienced during the second half of the twentieth century an important increase of its permanent and seasonal population. Since 1999, the city has been grouped together with 17 others municipalities (communes) into an intercommunality (cooperation group between communes): La Rochelle's community of Agglomeration (CDA-LR), fig 1.

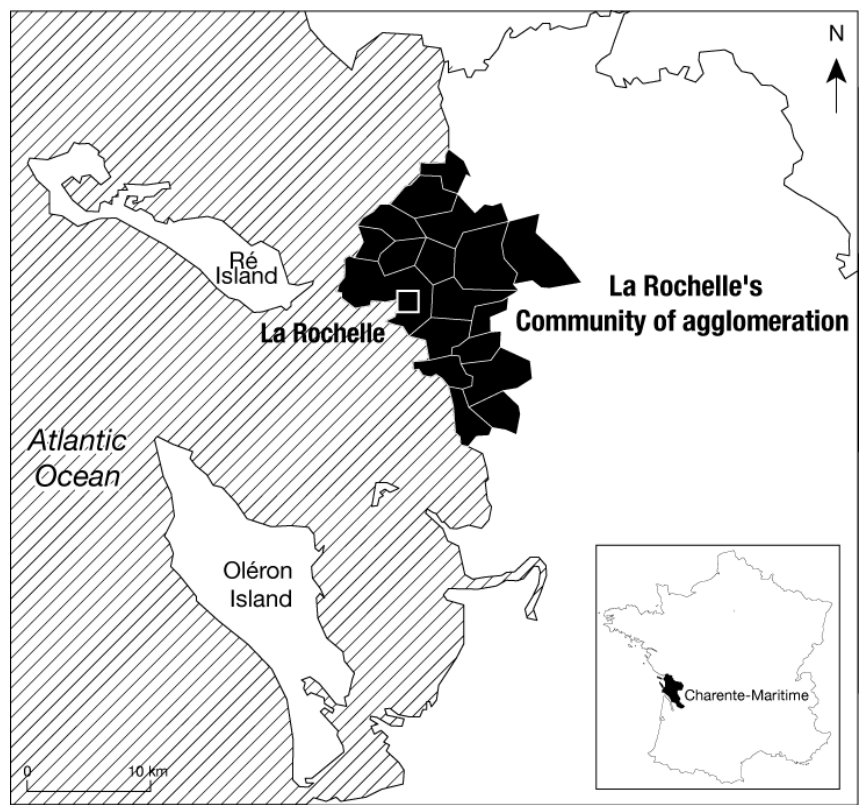

Figure 1: La Rochelle's community of agglomeration.

Because of its attractive coastal position, the CDA-LR is subjected to a fast growing population, which showed itself by a massive urban spread. This urban spread is constrained by a coastal position (physical constraints and planning regulations). This urban spread is today particularly visible in the peripheral municipalities (Communes) of the CDA-LR. These municipalities absorb the inhabitants because they cannot find housing inside the city of La Rochelle. The CDA-LR experiences a strong land pressure because of its attractive coastal position. Land use is highly regulated and the building is already very dense. Inhabitants are thrown back towards the periphery by the price of the housing. The control of urban spread in CDA-LR is one of the main challenges for the future land development plan (schema de coherence territorial: SCOT). The SCOT's elaboration is at present in progress.

The aim of this paper is to simulate two scenarios proposed by the SCOT. These scenarios are simulated thanks to an agent based model. Cadastral dataset, large scale geographical data bases are used as an input. To implement the SCOT, urban engineers and elected representatives need information regarding 
the impacts of urban spread on the intercommunality. The first part of this paper presents the institutional and scientific context of this research. The second part focuses on the methodology and describes the cadastral dataset, as well as modelling tools implemented in NETLOGO, an agent based simulation software. Then, the results are presented and discussed. The prime aim is in fine to better understand the specificities of the urban spread process on coastal areas.

\section{Research background}

This research is in keeping with two programs that have different aims. This research is also in relation to a rich scientific context: agent based modelling with geographical data in an urban problematic.

\subsection{Institutional context}

This project is led in partnership with La Rochelle's community of agglomeration. La Rochelle's community of agglomeration makes cadastral data available to the University researchers. These data are managed in France by the Ministry of Finance (Direction Générale des Impôts: DGI) and owned by CDALR.

This research is included in a coastal and environment observatory (ECOP). Several departments, including the urban spread observatory, constitute this observatory. It provides a thematic approach and facilitates multidisciplinary approaches. This study also joins an IT research program (ESTE program) granted by the Poitou-Charentes region. This one is more focused on space and time tools implementation, time data management, spatial simulation and analysis.

\subsection{Scientific context}

Many scientific fields deal with urban sprawl, its casualties, and the ways to predict it. A French geographer scientist, Levy [1], has developed some predictive scenarios. These scenarios are based on long-time evolution in order to explore urban structures and their transformations on the long-term (e.g. centrality analysis). French national statistic agency (INSEE) has developed, since 1996, new statistical tools in order to analyse urban sprawl in a sharper way: INSEE is now using new methods to define more precisely "Urban area". Eventually, urban planning models, such as Antony's [2] on Belfort, or Hasse and Richard's [3] on American cities, were developed to help planning evolution. These models help to quantify and localize a town's evolution from a cellular space.

More recently, simulation research, based on multi agent paradigm - Banos et al [4], Badariotti et al [5] or Rousseaux [6] - shows an abundance of tools and methods for such analysis. It also shows connectivity with other fields: Daudé and Langlois [7] use Schelling's model [8], borrowed from economists in order to study urban segregation. In the field of urbanism and geography, studies of European cities' shape were treated in many researches. Guerois' thesis [9] deals 
with the links between urban morphology and sustainable development and compares densities of several large European cities.

Within this vast field of research, this paper aims at better understanding the reasons which explain, at least partly, urban sprawl, through the analysis of an urban document: the SCOT.

\section{The SCOT document, towards a sustainable city?}

In France, the SCOT is a document, which is relatively recent, as the concept of sustainable city. It was created within the framework of the loi $S R U$ : "Solidarity and urban renewal law" (December 13 $\left.3^{\text {th }}, 2000\right)$. It replaces the Schéma directeur: a large scale urban plan which was created in 1967 and modified in 1983. The SCOT has to be consistent with the sustainable development requirements. One part of this document is moreover entitled "Project of planning and sustainable development". On one hand, the SCOT allows the connection between various public policies (town planning, economic development, transport, environmental protection...). On the other hand, by proposing scenarios, it aims at anticipating the future to think better the present. It is also a strategic document, which supplies a legal framework to which every document of operational planning has to conform. Finally, it expresses the will to consider urban planning at the intercommunality scale. Within an institutional territory, the project designed in the SCOT should correspond as much as possible to the populations' territory of life.

In this field, the city of La Rochelle has been a pioneer. In France counting 36000 communes, La Rochelle used very early the possibilities offered by intercommunal grouping (Joxe-Marchand law, February $6^{\text {th }}$, 1992). It was the only major town of Poitou-Charentes region to establish a group of communes (Communauté de Ville: CV) from 1993. In five years, the intercommunal perimeter had doubled, from 9 communes in 1993 to 18 communes since 1998. This widened perimeter has allowed the CV to become CDA on January 1st, 2000 (Chevènement law, July 12th, 1999). This CDA-LR is the most populated urban intercommunality of Poitou-Charentes. It accounts 146,121 inhabitants in 2006, being ahead of Poitiers' CDA, nevertheless the regional capital. Since 1998 , its perimeter approximately includes $80 \%$ of the urban area population against only two thirds for Poitiers Community of agglomeration.

This example of territorial integration is inscribed in the global approach of the sustainable city. Thanks to the durability of the municipal teams - Michel Crépeau was mayor from 1971 till 1999 - La Rochelle has been inventing the urban ecology in France from the 1970s: selective sorting of the waste, pedestrian sector in city centre, bikes in self-service, electric vehicles. More generally, it is the permanent search for equilibrium which seems to have guided local public policies for 30 years: equilibrium between the will to become a metropolis (creation of the university), while preserving the attributes of a human-sized city; equilibrium between an essential economical development to erase the scars of a serious industrial crisis (decade 1980) and the wish to protect a qualitative environment. 
It is into this context that the CDA-LR launched the SCOT elaboration process in 2006. The main stages of this document's elaboration are:

- June, 2th, 2006: Decision to transform the "Schéma directeur" into the SCOT.

- 2007: Elaboration of the territorial diagnosis and the initial state of environment.

- 2008: Elaboration of the scenarios. Presentation of the scenarios through an itinerant exhibition across the territory.

- 2009: Choice of the priority scenario and writing of the SCOT document.

- 2010: Project subjected to validation and to survey.

One of the main stakes for elected representatives of La Rochelle is to demonstrate their capacity to innovate in the environmental field, all the more that in France, social and political expectations are particularly high: organization of the national forum "Grenelle de l'environnement" in 2008, high score for the ecologist political list "Europe Ecologie" at the European election in 2009. Balance between growth and sustainability is carefully looked at, as the speech given by La Rochelle mayor (and president of the community of agglomeration) in March 2009 in a public meeting related to the SCOT, illustrates it: "Our aim is not growth for growth. We can grow but what we want is a well balanced development" "Notre objectif n'est pas la croissance pour la croissance. Nous pouvons grandir mais nous voulons un développement équilibré".

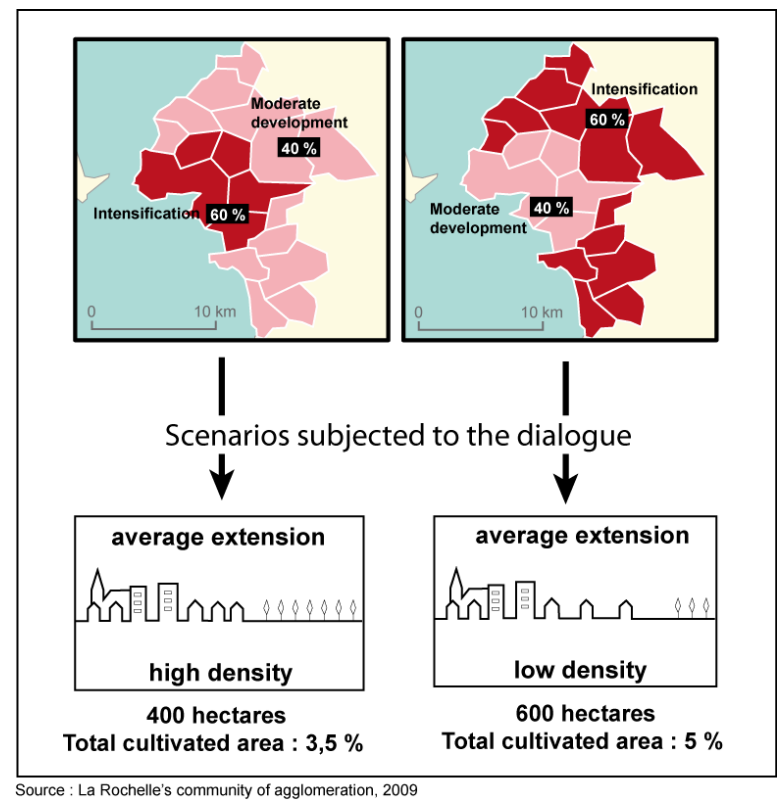

Figure 2: Growing scenarios in the CDA-LR. 
The launch of an Agenda 21 process on the territory was also announced during the same meeting. Moreover, the main objective of the meeting was to debate on the different scenarios regarding territorial evolution up to 2020, fig 2 .

The first scenario considers a growth shared out between a first central unit (the city of La Rochelle and its inner suburbs) that would catch $60 \%$ of the population growth rate from today to 2020 (15,000 inhabitants more) and the outer suburb with a controlled extension (40\% of the growth rate: $+9,000$ inhabitants). A disconnection between first and second ring would be maintained. The second scenario means on the contrary a moderate growth of the first central unit $(9,000$ inhabitants: $40 \%$ of the population growth rate) with the beefing up of the whole outer suburb $(+15,000$ inhabitants $)$. In the latest scenario, outer suburb would catch the most important part of the population growth rate $(60 \%)$ until 2020 . Sustainability of the city's development is impacted quite differently according to the scenario that is considered.

That is why testing both scenarios thanks to an urban growth model is interesting. This model helps at simulating future constructions on CDA-LR depending on the two urban choices proposed by the SCOT. Which is the most sustainable-compatible scenario?

\section{Dataset and modelling}

This part focuses on the description of dataset and methods used for the urban growth simulation. The first part describes cadastral dataset and other large-scale data. Cadastral dataset contains information regarding building dates, which are stored in a cadastral matrix. From this information, the urban spread will be studied. Methodology is described in a second part and focuses on the implementation of the urban growth model.

\subsection{Cadastral dataset}

Dataset consists in digital map files, which contain parcel-level cadastral information (between 1/2000 and 1/5000). In France, cadastral dataset used to be in paper format, but a numeric version has been made available for a dozen years (numeric cadastral plan) in raster or vector. Vector data are used for this research. Cadastral dataset contains two types of graphic information: parcels and buildings. All the semantic information is linked to cadastral parcels. Building is linked to cadastral parcels thanks to its geographical position: "a building is inside a parcel". Cadastral dataset also contains semantic information. Concerning time information, it is important to note that only "building date" is available. If building is modified or destroyed, there is no information concerning these changes. Because of these restrictions, this study does not deal with urban changes or destructions of building. At the scale of the intercommunality, changes and destructions are anecdotic and do not have any influence on global urban spread phenomenon. Cadastral data help at calibrating the model: global trends are outlined with observing building construction from 1950 to today, fig 3. The model checks that simulated results stick as close as possible to this trend. 


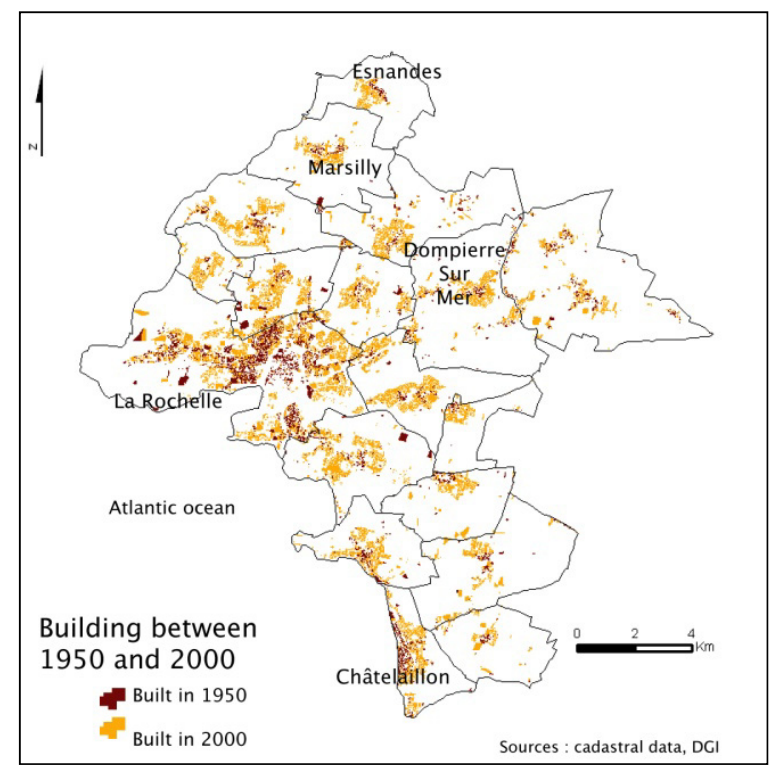

Figure 3: $\quad$ Building construction from 1950 to today in the CDA-LR.

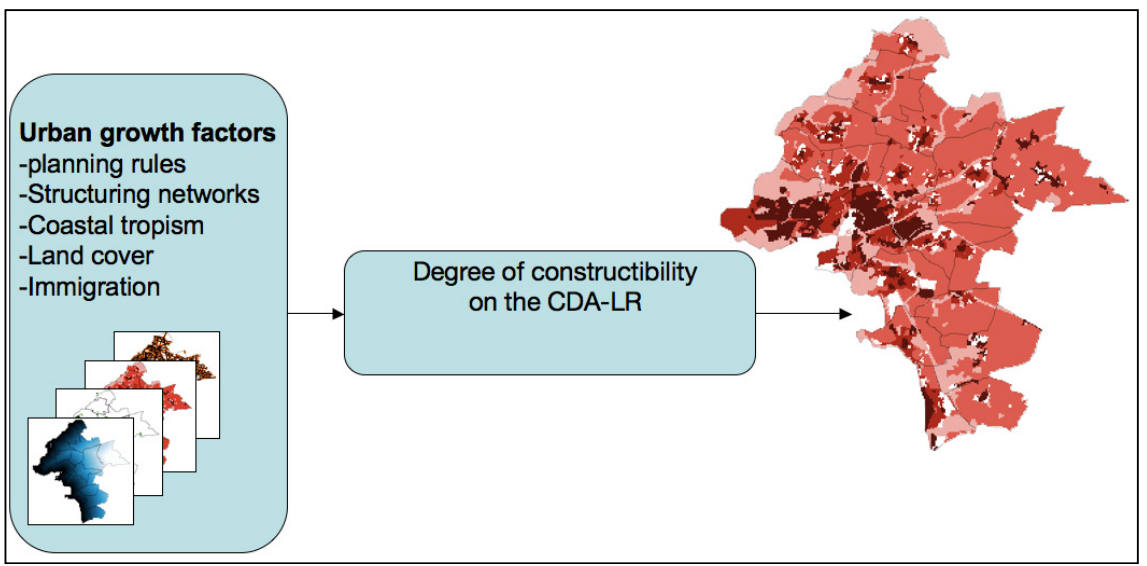

Figure 4: Description of the modelled geographical space.

\subsection{Description of the other data used}

In order to describe the geographical space, a large-scale database is used. It was provided by the French national mapping agency. Extracted data are integrated into the model and concern land use and road network. Land use is integrated as a "cost grid" where each cell contains construction probability (e.g. swamps have a very low score, agricultural areas have a high score). A road network is also 
integrated and prioritized depending on its category (e.g. motorway, first road...). Immediate proximities to nodes (e.g. crossroads) are favoured. Then, as for land use, a "cost" grid is computed.

Urban documents, such as Plan Local d'Urbanisme (legal city plan) and SCOT are also integrated into the model as "cost" grid. Each grid can be weighted. Then, all the grids are merged and the geographical space is described in the result grid, fig 4. Other grids need to be integrated into the model: Land price is one of the main useful data for urban sprawl studies but it is hardly available on the CDA-LR territory.

\subsection{The modelling}

After having described the space with weighted "cost" grids, this part focuses on the description of the urban sprawl modelling. The modelling is based on a multi agent simulation paradigm. Agents are described as a group of new population. Agents will build on cells that satisfy them the most. This satisfaction is computed from the "cost" grid described in the previous part. Urban sprawl's modelling also uses a propagation principle. This principle favours construction firstly on neighbourhood of constructed cells (common Moore neighbourhood). Social segregation is also integrated in the model. It is based on a Schelling [8] model adaptation. Different classes are implemented (rich, poor, medium) based on agent richness. An agent prefers to settle near agents from the same social class. Other agents are described in the model: each commune of the group of commune (the CDA-LR) is modelled as an agent. Each commune of the CDA-LR has a specific behaviour concerning urban policy. Even if urban policies of the CDA-LR have to be as global as possible, each commune actually manages its own urban policy. Despite a common planning document (the SCOT), some communes will have expansionist behaviour, while other communes will have a more protective behaviour and will as a consequence introduce a more restrictive legal urban plan. The model assesses each commune's urban policy based on two simple criteria: expansionist or protective behaviours.

\section{First results}

Model has been computed with two different space descriptions, fig 5. Each description matches with the two scenarios developed in the SCOT document. The first scenario (S1) shows a political will to curb urban sprawl and favours densification. It also shows a disconnection between the central urban unit and the other peripheral communes.

The second scenario (S2) does not constrain urbanization and "lets the city live"; consequences are a massive urban sprawl, all around the first ring. The model materialises urban growth of the CDA-LR depending on the two scenarios of the SCOT, but, as a model, does not predict which one is more likely to happen. Major limits, especially spatial limits, will be discussed in the following section. 

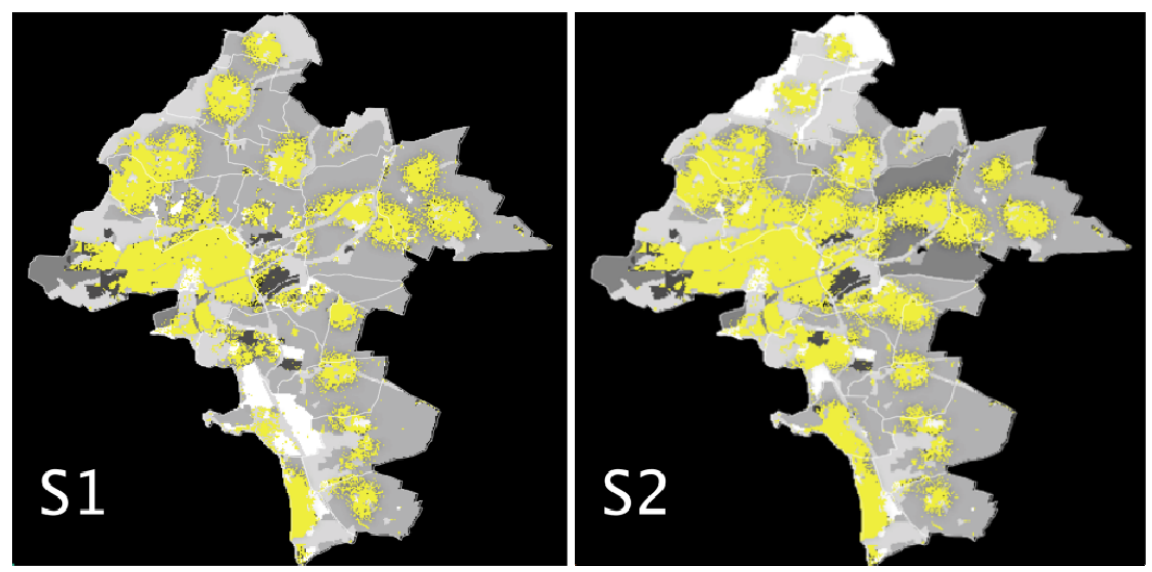

Figure 5: Modelling of the two scenarios.

\section{Discussion}

Because it is more consistent with the "ideal sustainable" city, the first scenario is preferred by the elected representatives. Economically speaking, the main central urban unit would keep increasing its metropolitan functions and would optimize its existing means of transport. Socially speaking, the first scenario favours service and neighbourhood shops for the two major social classes living in the central area: low income families and seniors. Environmentally speaking, the first scenario favours green areas, preserves biodiversity and consumes a few agricultural lands. The first scenario would indeed be of great help for the protection of coastal and agricultural areas. By choosing to densify the main central unit (La Rochelle), it would lead to decreased energy costs, which are often induced by urban sprawl (e.g. greenhouse gas effect). However, this scenario seems very ambitious. It would mean a doubling of population growth rate in the central urban area: $(0,99 \%$ versus $0,41 \%$ for $99-06)$. This would be quite antinomic with the on-going increase of land price in this space. Moreover, in order to persuade population that densification is a good choice, elected representatives from CDA-LR would have to convince the inhabitants that a "compact city" (which is different with "dense city") shows more advantages than drawbacks: how to offer enough green areas in the city to satisfy widespread individual private garden aspiration?

The economic cost of the compact city may also be a problem since it is evaluated as higher than the spread city's one [10]. Eventually, the efficiency of the CDA-LR perimeter remains a question since planning urban growth would require one to take into account larger perimeters: between 1999 and 2006, residential attraction has decreased in the CDA-LR but has strongly increased outside the CDA-LR, particularly along the major highway La Rochelle - Niort, fig 6 . 


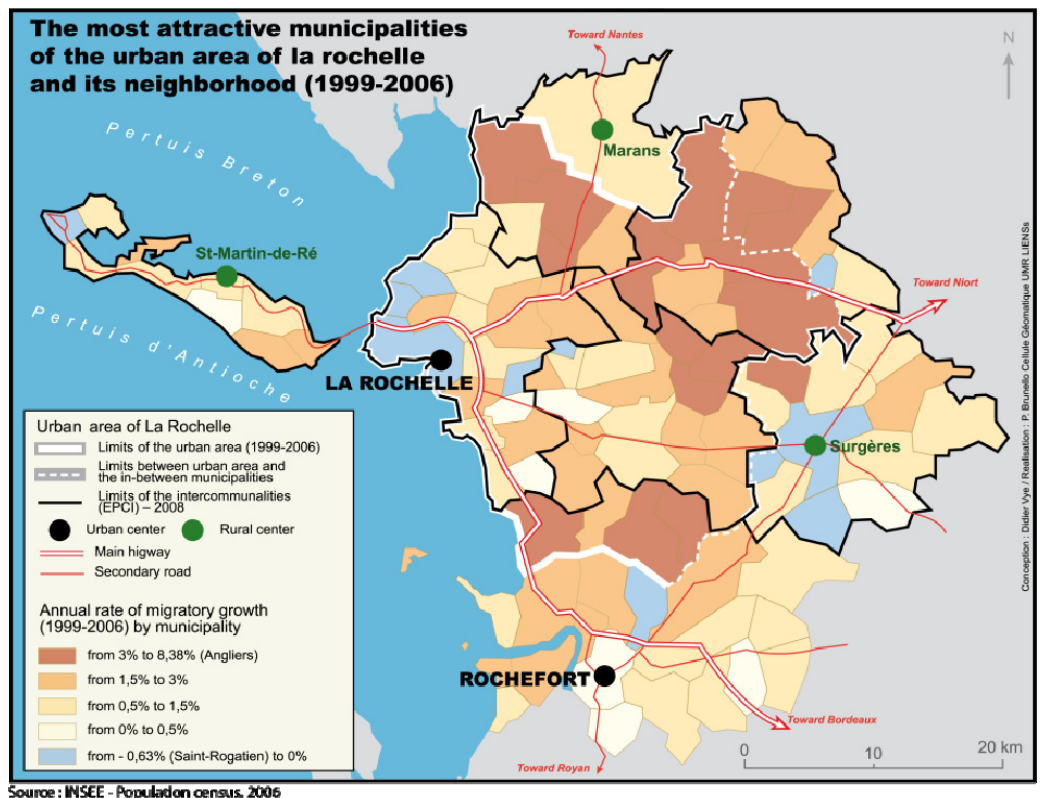

Figure 6: An urban growth beyond the CDA-LR perimeter.

These communes offer interesting advantages: available lands, few urban constraints (e.g. no coastal preservation law), and urban strategies which favour urbanization by attracting young couples with children with easy accommodation facilities. The intensity of this urban sprawl outside the CDA-LR illustrates the gap between the urban area perimeter and the intercommunality area perimeter. Although this situation is not much original in France $[11,12]$, this gap has clearly increased since 2000 on our studied area. Another intercommunality "le Pays d'Aunis" located East from the CDA-LR has chosen to elaborate its own large urban planning (SCOT) in 2004. But this option has had for consequences to include communes that used to belong to the previous La Rochelle's large scale urban plan (2001 Schéma Directeur).

The SCOT perimeter, as designed in 2007, is restricted to the 18 communes belonging to CDA-LR. For S. Tallard, the elected representative in charge of the SCOT: "the next objective would be to create conditions of a SCOT, maybe at the urban area scale" "créer les conditions d'un SCOT peut-être à l'échelle de l'aire urbaine" (public meeting, March 2009). Then, a lot of collaborations were organized during 2009, including an important study on mobility and transportation problematic. It is a major topic for the today's "sustainable city".

\section{References}

[1] Levy, J-P., 1991. Villes et territoires. 3, La réhabilitation des quartiers anciens et de l'habitat existant: acteurs, procédures, effets et conséquences sociales. Presses universitaires du Mirail-Toulouse, $173 \mathrm{p}$. 
[2] Antony, J-P., 2007. Calibrer un modèle d'évolution de l'occupation du sol urbain. L'exemple de Belfort, Cybergeo, Systèmes, Modélisation, Géostatistiques, paper $\mathrm{n}^{\circ} 347$.

[3] Hasse, J-E. et G. Richard, 2003. Land Resource Impact Indicators of Urban Sprawl, Applied Geography, Vol 23/2-3 pp 159-175.

[4] Banos, A., Chardonnel, S, Lang, C, Marilleau, N, Thevenin, T, 2005. Simulating the swarming city: a MAS approach. In procs. of The 9th Int. Conf. on Computers in Urban Planning and Urban Management, CUPUM 2005, London, UK, June 2005, 15p.

[5] Badariotti, D., Banos, A., Moreno, D., 2007. Conception d'un automate cellulaire non stationnaire à base de graphe pour modéliser la structure spatiale urbaine: le modèle Remus, Cybergeo, online on 3rd October 2007.

[6] Rousseaux, F., 2009. Estevol, a space and time analysis tool for ArcGIS. Proceedings of the 23th international user conference ESRI (ESRI UC), San Diego.

[7] Daude E. \& Langlois, P, 2007. Comparison of Three Implementations of Schelling's Spatial Segregation Model, in D. Phan, F. Amblard (ed.), Agent-Based Modeling and Simulation in the Social and Human Sciences, The Bardwell Press, Oxford.

[8] Schelling, T., 1971, Dynamic Models of Segregation. Journal of Mathematical Sociology 1:143-186

[9] Guerois, M., 2003. Les formes des villes européennes vues du ciel: une contribution de l'image CORINE Land cover à la comparaison morphologique des grandes villes d'Europe occidentale. $\mathrm{PhD}$ thesis of the University of Panthéon-Sorbonne - Paris 1.

[10] Castel J.C., 2007, Coûts immobiliers et arbitrages des opérateurs: un facteur explicatif de la ville diffuse, Annales de la recherche urbaine, $\mathrm{n}^{\circ} 102$.

[11] Estebe P., 2008, Gouverner la ville mobile, intercommunalité et démocratie locale, Paris, PUF, Coll. "La ville en débat", 76 p.

[12] Roux, E. \& Vanier, M., 2008, La périurbanisation, problématiques et perspectives, Paris, La Documentation française, Coll. "travaux", 88 p. 